\title{
(a) Persistent ST-segment elevation due to cardiac metastasis
}

\author{
Tony Chen
}

Internal Medicine, University of Michigan Health System, Ann Arbor, Michigan, USA

\section{Correspondence to} Dr Tony Chen,

ctony@med.umich.edu

Accepted 11 May 2017

\section{DESCRIPTION}

A man aged 68 years with a known history of squamous cell carcinoma of the lung presented to the emergency room complaining of an acute episode of dyspnoea. His symptoms had resolved on presentation to the hospital. An EKG was obtained, which showed marked ST-segment elevation (STE) in the anteroseptal leads (figure 1A). No prior EKG was available for comparison. The patient denied any chest pain or pressure, and had no evidence of myocardial necrosis by cardiac biomarkers. Nevertheless, he was taken emergently to the cardiac catheterisation laboratory for a presumed diagnosis of STE myocardial infarction (STEMI). He was found to have severe two-vessel coronary artery disease with possible plaque rupture in the mid-left anterior descending artery (LAD) (figure 2). Overlapping bare metal stents were deployed to the LAD. Concerningly, the patient's right ventricle was noted to be in a fixed motion suggestive of tumour infiltration.
A transthoracic echocardiogram was subsequently performed, which demonstrated a large right ventricular mass with involvement of the interventricular septum and pericardium (figure 3). A CT of his thorax showed an anterior mediastinal mass invading the pericardial space, right ventricular free wall and the right ventricular outflow tract (figure 4). Despite the percutaneous coronary intervention, the STE persisted while the serial cardiac biomarkers remained negative (figure 1B). Additionally, the patient also continued to deny any cardiac symptoms. It was later believed that the STE was likely due to tumour infiltration into the right ventricle, and unlikely to be the classic STEMI due to acute coronary syndrome with resultant occlusive thrombus.

The differential diagnosis of STE is broad and extends beyond acute myocardial infarction (AMI). Once AMI is ruled out, other relatively more common considerations include acute pericarditis, Prinzmetal's angina, hyperkalaemia, left ventricular
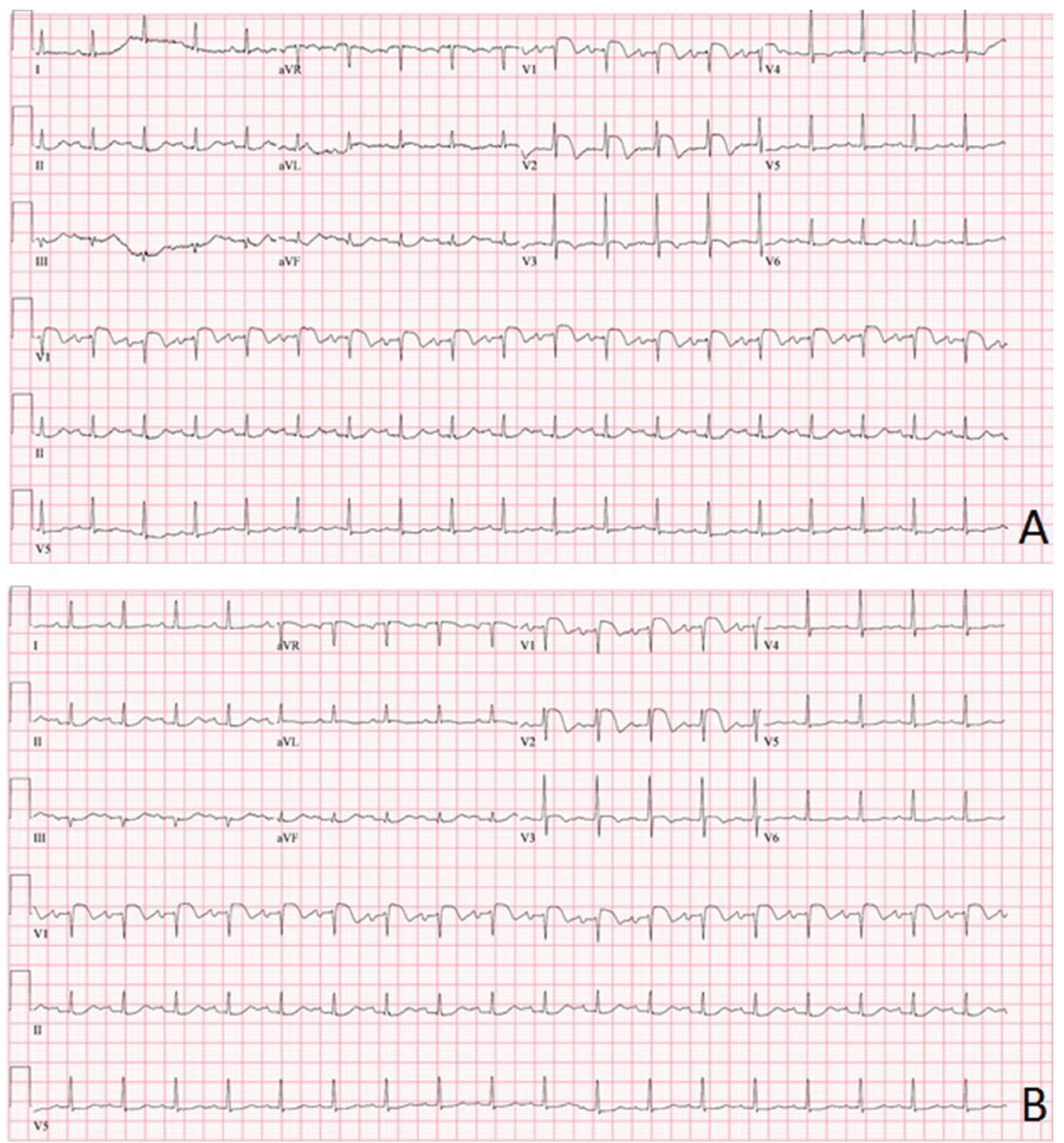

Figure 1 (A) EKG on presentation to the hospital, showing ST-segment elevation in leads V1 and V2. (B) Repeat EKG after percutaneous coronary intervention showing persistent ST-segment elevation in leads V1 and V2. 


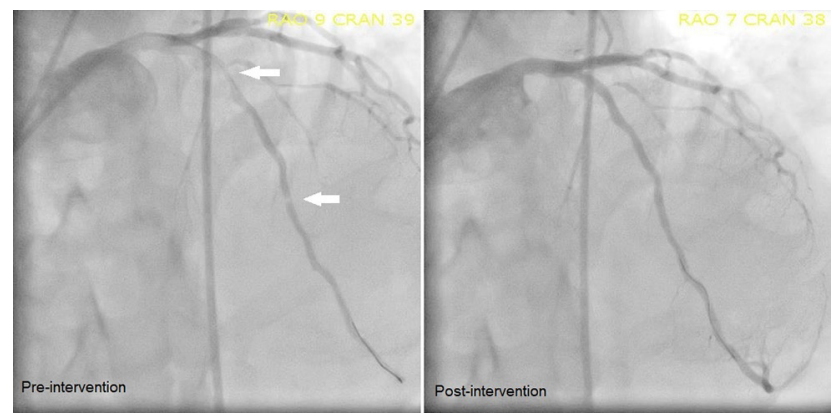

Figure 2 Coronary angiogram showing the left anterior descending artery in both the preintervention and postintervention views from the right anterior oblique with cranial angulation (RAO CRAN) perspective.

hypertrophy, left bundle-branch block, Brugada syndrome and pulmonary embolism. ${ }^{12}$ Although relatively rare, STE due to metastatic tumour involving the myocardium had been described in published literature dating five decades back. Although the mechanism of this phenomenon remains unclear, one hypothesis centres around the idea of an injurious current resulting from the inflammation surrounding the tumour, ionic transfer of potassium from necrotic tissue with resultant electropotential difference and neoplastic stretch of adjacent muscle fibres. ${ }^{23}$ In this article, we presented a case of a patient who was initially presumed to have a STEMI based on EKG findings, but was later found to have myocardium compression and infiltration from lung metastasis. He did not have evidence of direct tumour invasion to the LAD on his coronary angiogram. His persistent STE and negative serial biomarkers despite coronary stent placement (as well as absence of angina symptoms) supports this change in diagnosis. Our patient had previously tried palliative carboplatin and paclitaxel with progression of disease. He had been subsequently enrolled in the Lung Cancer Master Protocol (Lung-MAP) trial and had been treated with nivolumab and ipilimumab prior to this admission. Unfortunately, he had continued to demonstrate tumour growth and had been ultimately switched to gemcitabine for a brief moment without improvement. Given his overall disease progression and poor prognosis, the patient declined additional

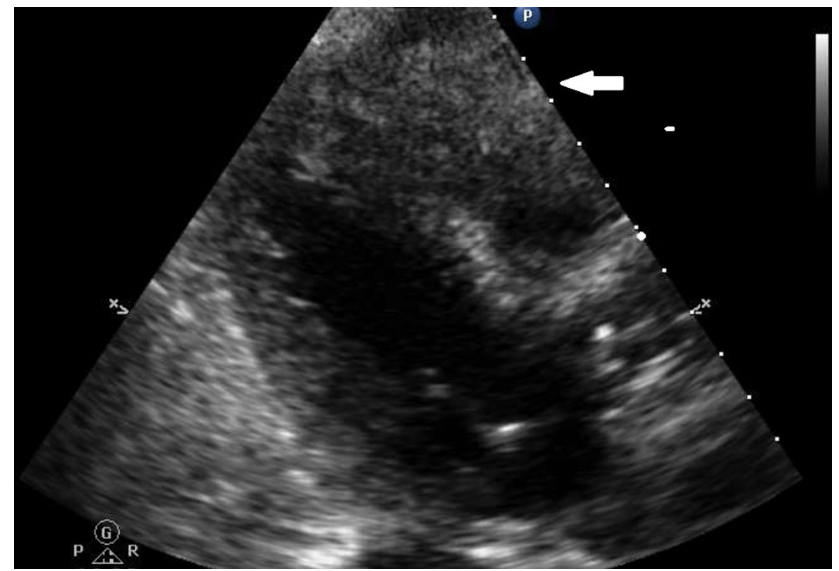

Figure 3 Parasternal long-axis view in echocardiogram showing an infiltrating mass in the right ventricle (arrow).
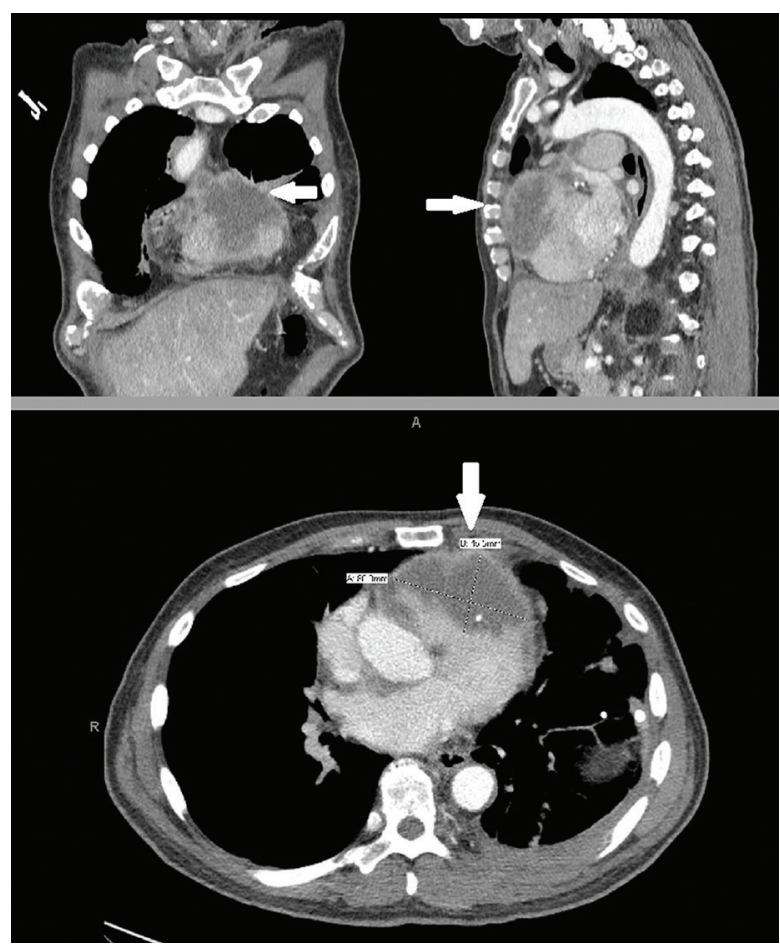

Figure $4 \mathrm{CT}$ of thorax showing tumour infiltration into the myocardium (arrow) in three different views, coronal (top left), sagittal (top right) and transverse (bottom).

\section{Learning points}

- The differential diagnosis of ST-segment elevation is broad, but the most important and time-sensitive diagnosis to consider is acute myocardial infarction.

- If a patient with known malignancy presents with an isolated ST-segment elevation without a clinical presentation suggestive of acute coronary syndrome, tumour compression and/or infiltration of the myocardium should be considered in the differential diagnosis.

chemotherapy during this admission and wished to pursue hospice care. He passed away 2 weeks later.

Competing interests None declared.

Patient consent Consent obtained from next of kin.

Provenance and peer review Not commissioned; externally peer reviewed.

Open Access This is an Open Access article distributed in accordance with the Creative Commons Attribution Non Commercial (CC BY-NC 4.0) license, which permits others to distribute, remix, adapt, build upon this work non-commercially, and license their derivative works on different terms, provided the original work is properly cited and the use is non-commercial. See: http://creativecommons.org/ licenses/by-nc/4.0/

(C) BMJ Publishing Group Ltd (unless otherwise stated in the text of the article) 2017. All rights reserved. No commercial use is permitted unless otherwise expressly granted.

\section{REFERENCES}

1 Wang K, Asinger RW, Marriott HJ. ST-segment elevation in conditions other than acute myocardial infarction. N Engl J Med 2003;349:2128-35.

2 Shah S, Padaliya B, Mohan SK. Noninfiltrating adenocarcinoma of the lung causing ST-Segment elevation. Tex Heart Inst J 2015;42:381-4.

3 Hartman RB, Clark PI, Schulman P. Pronounced and prolonged ST segment elevation: a pathognomonic sign of tumor invasion of the heart. Arch Intern Med $1982 ; 142: 1917-9$ 
Copyright 2017 BMJ Publishing Group. All rights reserved. For permission to reuse any of this content visit http://group.bmj.com/group/rights-licensing/permissions.

BMJ Case Report Fellows may re-use this article for personal use and teaching without any further permission.

Become a Fellow of BMJ Case Reports today and you can:

- Submit as many cases as you like

- Enjoy fast sympathetic peer review and rapid publication of accepted articles

Access all the published articles

Re-use any of the published material for personal use and teaching without further permission

For information on Institutional Fellowships contact consortiasales@bmjgroup.com

Visit casereports.bmj.com for more articles like this and to become a Fellow 